\title{
Role of Tissue Factor in Venous Thrombosis
}

\author{
David A. Manly ${ }^{1}$, Jeremiah Boles ${ }^{2}$, and Nigel Mackman ${ }^{2}$ \\ Nigel Mackman: nmackman@med.unc.edu \\ ${ }^{1}$ East Carolina University, Brody School of Medicine, Greenville, North Carolina 27834 \\ 2Division of Hematology/Oncology, Department of Medicine, University of North Carolina, Chapel \\ Hill, North Carolina 27599
}

\begin{abstract}
Venous thromboembolism (VTE) is a leading cause of morbidity and mortality worldwide.

However, the mechanisms by which clots are formed in the deep veins have not been determined. Tissue factor (TF) is the primary initiator of the coagulation cascade and is essential for hemostasis. Under pathological conditions, TF is released into the circulation on small-membrane vesicles termed microparticles (MPs). Recent studies suggest that elevated levels of MPTF may trigger thrombosis. This review provides an overview of the role of TF in VTE.
\end{abstract}

\section{Keywords \\ coagulation; microparticles}

\section{INTRODUCTION}

Venous clots are fibrin rich and are treated with anticoagulant drugs. Tissue factor (TF) is a $47-\mathrm{kDa}$ transmembrane glycoprotein that is the primary initiator of coagulation in vivo (1). However, until recently few studies had investigated the role of TF in venous thrombosis. TF is constitutively expressed in perivascular cells and is essential for hemostasis. Vessel injury exposes extravascular TF to factor VII/VIIa in blood and allows for the formation of a TF-factor VIIa complex. Importantly, TF increases the catalytic activity of factor VIIa two million-fold (2). The TF-factor VIIa complex activates both factor X and factor IX, which results in the formation of thrombin and ultimately cross-linked fibrin. This review discusses our current understanding of the cellular sources of TF that may trigger venous thromboembolism (VTE).

\section{TISSUE FACTOR EXPRESSION}

Under normal conditions, TF is not expressed by vascular cells that are in contact with the blood, including vascular endothelial cells (ECs). One exception is the very low levels of TF in a subset of CD14-positive monocytes (3). In contrast, high levels of TF are expressed by pericytes and adventitial fibroblasts in and around the vessel wall and by epithelial cells surrounding organs and at body surfaces (4-6). Therefore, TF is localized predominantly to the tunica media and tunica adventitia in blood vessels, which prevents inappropriate

Copyright () 2011 by Annual Reviews. All rights reserved

DISCLOSURE STATEMENT

N.M. is a consultant for Daiichi-Sankyo. D.A.M. and J.B. are not aware of any affiliations, memberships, funding, or financial holdings that might be perceived as affecting the objectivity of this review. 
activation of coagulation in the absence of vascular injury. In addition, TF is expressed in the parenchyma of highly vascularized organs such as the placenta, brain, heart, kidneys, and lungs and protects these organs from excessive hemorrhage $(4,5)$.

Numerous studies have demonstrated the induction of TF expression in peripheral blood monocytes in various disease states. For instance, exposure of monocytes to bacterial lipopolysaccharide (LPS) induces TF expression (7). Some studies have found that platelets contain TF mRNA and protein, whereas other studies have failed to detect TF in platelets (8-14). Despite the fact that cultured ECs express TF after stimulation (15-17), evidence for TF expression by ECs in vivo is very limited (18-25). In one study, TF staining on the surface of ECs in the aortas of septic baboons colocalized with the leukocyte marker Pselectin glycoprotein-1 (PSGL-1), which suggests that some of the staining was due to the binding of leukocyte-derived, TF-positive microparticles (MPs) (see below) (21).

\section{VENOUS THROMBOSIS}

VTE, a disease characterized by the development of deep-vein thrombosis (DVT) and/or pulmonary embolism (PE), is a cause of substantial morbidity and mortality worldwide. Studies have estimated that in the United States 900,000 patients develop VTE annually and that 300,000 of those patients die due to PE (26-28). VTE is a multifactorial disease that can be influenced by genetic factors (e.g., factor V Leiden, prothrombin 20210 gene mutation), acquired factors (e.g., antiphospholipid antibodies), and environmental factors (e.g., immobility, surgery). VTE is thought to be triggered by alterations in the blood composition (thrombophilia), changes in blood flow (e.g., stasis), and/or activation of the endothelium. Venous thrombi are fibrin-rich clots that form on the surface of the endothelium in the absence of gross vessel wall injury (29).

Under normal conditions the endothelial surface inhibits coagulation because of the presence of various proteins, such as tissue factor pathway inhibitor (TFPI), thrombomodulin (TM), and the endothelial cell protein C receptor (EPCR) (30). In addition, the proteoglycans heparan sulfate and dermatan sulfate bind the anticoagulants antithrombin and heparin cofactor II (30). However, physical (e.g., vascular damage) or functional (e.g., hypoxia) perturbation of the endothelium promotes thrombosis due to reduced expression of anticoagulants and the induction of TF expression (31). A majority of DVTs occur within the valve pockets of deep venous valves, which are exposed to periods of stasis and low oxygen levels (32). Venous valves have adapted to this phenomenon by expressing higher levels of TM and EPCR (32). However, despite this additional protection, valve pockets are thought to be the most common site of thrombosis (33). Recent studies have investigated the role of TF in venous thrombosis.

\section{STASIS: VESSEL WALL TISSUE FACTOR}

Numerous studies have shown that venous stasis plays a significant role in the pathogenesis of VTE. Gibbs (34) demonstrated that the risk of DVT increases in parallel with the amount of time that a patient is bedridden. Furthermore, DVT occurs more frequently in the paralyzed limb of a hemiplegic patient compared with the unaffected limb and equally frequently in the two limbs of a paraplegic patient (35). The increased risk of VTE associated with immobility diminishes with ambulation or the use of pneumatic leg compression devices (36).

Deep venous valve pockets are naturally susceptible to periods of blood stasis and constitute the primary location of thrombus formation in veins (32). Venous valve pockets assist blood return to the right atrium of the heart by preventing backflow of blood in response to gravity. Muscular contractions in the leg and thigh facilitate blood return to the heart by compressing 
the deep veins. In the absence of activity (e.g., immobility or bed rest), there are reduced blood flow and stasis in the deep valve pockets. Teleologically, it appears that the higher levels of TM and EPCR expression provide extra anticoagulation protection to the endothelium at these locations (32). However, as blood stasis persists, the ability of the endothelium to prevent coagulation diminishes. This occurs through two primary mechanisms: (a) the accumulation of prothrombotic substances within the valve pocket and (b) local hypoxia. Normally, prothrombotic substances within the valve pocket are washed downstream and are inactivated in the capillary beds of the lungs, which are coated with TM and heparan sulfate (37). Thus, an alteration in blood flow can result in the accumulation of numerous prothrombotic agents, such as TF-positive MPs and thrombin. In addition, measurement of oxygen pressure in valve pockets demonstrates that hemoglobin undergoes rapid desaturation under static conditions, leading to hypoxic responses in leukocytes, platelets, and ECs (38). Hypoxia stimulates TF expression on cultured monocytes and concomitantly increases the release of TF-positive MPs $(39,40)$. Furthermore, the exposure of ECs to hypoxic conditions results in P-selectin expression, thereby creating a potential docking site for nascent TF-positive MPs, as well as for platelets, leukocytes, and leukocyteor tumor-derived MPs expressing PSGL-1 (41-43).

\section{BLOOD COMPONENT: MICROPARTICLE TISSUE FACTOR}

A decade ago, Giesen et al. (44) first reported that so-called circulating TF or blood-borne $\mathrm{TF}$ can contribute to the formation of an ex vivo thrombus. The authors suggested that circulating TF may enhance the propagation of a thrombus triggered by vessel wall TF through its ability to sustain thrombin production at the clot surface. The majority of circulating TF is in the form of MPs (also called microvesicles) (Figure 1). These are small $(<1-\mu \mathrm{M})$ membrane vesicles released from activated or apoptotic cells (45). TF-positive MPs may be generated from monocytes, ECs, vascular smooth muscle cells, tumor cells, and possibly platelets (1). One study using monocytic cells found that TF-positive MPs arise from distinct membrane microdomains where TF is colocalized with PSGL-1 (12). In healthy individuals, very low levels of TF-positive MPs are present in platelet-free plasma. Importantly, elevated levels of TF-positive MPs have been observed in patients with a variety of diseases, including cancer, cardiovascular disease, sickle cell disease, and endotoxemia (46-49). Many of these diseases are associated with VTE.

Reports using intravital microscopy revealed that hematopoietic cell-derived, TF-positive MPs contribute to thrombosis in mouse cremaster arterioles injured with a laser (50). Another study noted that TF was present only at the edges of hemostatic clots, although it was present throughout thrombotic clots (51). This suggested that TF-positive MPs are continuously incorporated into a nascent thrombus, although this study did not demonstrate that TF was functional. One likely mechanism for the accumulation of leukocyte-derived MP TF in growing thrombi is through the interaction of PSGL-1 on the MPs with P-selectin on the surface of the activated platelet or activated ECs $(42,52)$ (Figure 1).

\section{ANIMAL MODELS OF VENOUS THROMBOSIS}

Himber and colleagues (53) showed that the inhibition of TF reduced thrombus growth on a collagen-coated cotton thread inserted into the jugular veins of rabbits. Another study found that MPs from acute coronary syndrome patients triggered venous thrombosis in a rat model in a TF-dependent manner (54). In contrast to these data that support a role of MP TF in VTE, the role of cellular TF expression in VTE is less clear. Research efforts have utilized animal models to evaluate the role of TF expressed by different cell types. Ligation of the inferior vena cava (IVC) is frequently used to induce venous stasis, thereby promoting formation of venous thrombosis. One study showed that inhibition of the TF-factor VIIa 
complex reduced thrombosis in an IVC ligation model in nonhuman primates (55). In a rat model of IVC ligation, TF staining was observed in both leukocytes and ECs associated with the clot (56). However, these studies did not address the source of TF that drives thrombosis. One study showed that in healthy mice TF expression by non-bone marrow cells drove thrombosis without a detectable contribution of TF by bone marrow cells (57). More recently, investigators demonstrated that deleting the TF gene in myeloid cells reduced thrombosis in an IVC stenosis model (58). These results indicate that TF expression by both bone marrow and non-bone marrow cells contributes to thrombosis following IVC ligation. Further studies are needed to determine the cellular sources of TF that trigger venous thrombosis in other venous thrombosis models, such as the stenosis model that has minimal injury to the vessel wall.

\section{VENOUS THROMBOEMBOLISM AND CANCER: ROLE OF TUMOR-DERIVED MICROPARTICLE TISSUE FACTOR}

VTE remains a leading cause of cancer-associated morbidity and mortality (59). Cancer is associated with a fourfold increase in VTE, and the use of chemotherapy further enhances the risk of VTE to six- or sevenfold compared with the general population (60). Why do cancer patients have a higher risk of VTE? An early study by Dvorak and colleagues (61) found that tumor cells shed membrane vesicles (now termed MPs) that carry procoagulant activity. Furthermore, these researchers proposed that these MPs may account for the activation of the coagulation system associated with malignancy. Subsequent studies showed that TF is the major procoagulant activity of these MPs. Mouse tumor models have investigated the production and function of tumor-derived MPs. Human colorectal tumors grown in mice released TF antigen into the plasma (62). Interestingly, the level of the circulating TF was proportional to the size of the tumor, and tumors expressing higher levels of TF released more TF into the circulation. Davila and colleagues (63) found that human pancreatic tumors released TF-positive MPs into the circulation and that these MPs activated coagulation in a TF-dependent manner. Finally, researchers found that tumor-derived MPs enhance thrombosis in mice (43).

In humans, tumors expressing higher levels of TF are associated with a higher incidence of VTE (64). For instance, $28.3 \%$ of patients with pancreatic cancer, compared with only 5.7\% of colon cancer patients, develop VTE within a year of metastatic malignancy (64).

Moreover, the level of TF expression increases with an advancement of cancer $(65,66)$. One study showed that pancreatic cancer patients with tumors expressing high TF levels had a VTE rate of $26.3 \%$ compared with a $4.5 \%$ rate in patients with low TF expression. Importantly, several studies demonstrated that levels of circulating MPTF activity are significantly elevated in cancer patients $(47,67-70)$. A recent retrospective analysis using impedance-based flow cytometry to detect TF-positive MPs reported that tumor-derived TFpositive MPs are elevated in cancer patients with VTE compared with idiopathic VTE controls and non-VTE cancer controls (71). We measured MP TF activity in 11 pancreatic cancer patients over a 30-week period in a pilot study. We found that MP TF activity increased over time in two patients who developed VTE but that such activity remained at baseline in nine pancreatic cancer patients who did not develop thrombosis. This result suggested that MP TF activity may be predictive of cancer-associated VTE $(67,68)$. Taken together, these results suggest that MP TF may be the vehicle that transports the procoagulant activity from the tumor site to the deep veins to trigger thrombosis (72). 


\section{USE OF MICROPARTICLE TISSUE FACTOR AS A BIOMARKER FOR VENOUS THROMBOEMBOLISM RISK}

A recent study generated a risk-scoring model of predicting cancer-associated VTE (67). This scoring system was based on five criteria: $(a)$ site of cancer, $(b)$ hemoglobin level, $(c)$ body mass index, $(d)$ prechemotherapy leukocyte count, and $(e)$ prechemotherapy platelet count. Another biomarker for VTE risk in this patient population is soluble P-selectin (73). We and others have focused on circulating TF as a potential biomarker for assessing VTE risk in cancer patients. Several studies have correlated plasma TF antigen levels, MP TF levels via flow cytometry, or MP TF activity levels with VTE risk $(50,66,67,69-71,74)$. Studies in our lab have demonstrated that MP TF activity is significantly elevated in cancer patients with VTE compared with either non-VTE cancer controls or healthy plasma donors $(67,69)$. Moreover, researchers have reported that levels of TF-positive MPs in patients with advanced colorectal cancer correlate with levels of D-dimer, a fibrin degradation product that is strongly associated with VTE risk $(70,75)$. However, studies measuring MP TF activity levels report only a modest correlation between MP TF activity and D-dimer $(47,69)$. Currently, cancer patients routinely do not receive thromboprophylaxis. It is our hope that validated predictive models inclusive of known VTE risk factors will help to identify patients who will benefit from thromboprophylaxis.

\section{SURGERY AND TRAUMA}

Prior to routine thromboprophylaxis in surgical patients, the rate of DVT accompanying high-risk general surgery was estimated to be $30 \%$. In addition, $0.9 \%$ of those patients suffered a fatal PE (76). Today, the use of peri- and postoperative anticoagulants has reduced the risk of VTE. However, high-risk operations, such as lower-extremity orthopedic surgery (e.g., total hip or total knee replacement), still result in the development of symptomatic VTE in 1-3\% of patients (77). A recent study showed an increase in TF expression in peripheral blood mononuclear cells of patients receiving total knee arthroplasty. Interestingly, the increase in TF preceded the median time of diagnosis of VTE, suggesting that TF was involved in formation of the thrombus (78). Patients with severe trauma are also at significantly increased risk of VTE. Without prophylactic antithrombotic therapy, patients with major trauma develop thrombosis in 50-60\% of cases (79). Factors contributing to VTE in such patients are $(a)$ the release of procoagulant material in response to endothelial damage and inflammation, $(b)$ immobility, and $(c)$ reduced postoperative fibrinolytic activity (80). Nieuwland and colleagues (81) demonstrated a procoagulant state in patients undergoing cardiopulmonary bypass. Pericardial blood from these patients had significantly increased MPTF activity (81). These data suggest that endothelial damage and/or inflammation in surgical and trauma patients increase cellular TF expression, as well as the release of TF-positive MPs into the circulation, that promotes the development of VTE.

\section{TARGETING TISSUE FACTOR TO REDUCE VENOUS THROMBOEMBOLISM RISK}

Vitamin K antagonists and various forms of heparin are used to treat patients with VTE.
More recently, orally available factor Xa inhibitors and thrombin inhibitors have been
effective at reducing VTE in patients undergoing total knee and total hip replacement (82-
86). Although the inhibition of these downstream proteases reduces thrombosis, targeting TF
as the triggering event may be a more effective approach. Indeed, pharmacological
inhibition of TF reduces venous thrombosis in rabbits (53). However, as with all
anticoagulant therapy, a significant concern with inhibition of TF is bleeding. An alternative 
approach would be to inhibit the generation of MPs and/or the incorporation of MPs into a thrombus. Inhibition of p38 reduces MP generation in tumor necrosis factor $\alpha(\mathrm{TNF} \alpha)$ stimulated ECs (87). In addition, inhibition of P-selectin reduces VTE in animal models. Such reduction may be due in part to blocking the accumulation of leukocytes and leukocyte-derived, TF-positive MPs (88). This finding suggests that preventing the incorporation of TF-positive MPs into a growing thrombus may be a promising approach for future antithrombotic therapy.

\section{CONCLUSIONS}

There is increasing evidence that many diseases are associated with elevated levels of circulating TF in the form of MPs. Levels of MP TF may be a useful biomarker to identify patients at risk for VTE. Further studies are needed to elucidate the mechanism by which MPs bind to activated endothelium and platelets and trigger thrombosis.

\section{SUMMARY POINTS}

1. Tissue factor (TF) is the primary cellular activator of the coagulation protease cascade.

2. Microparticles (MPs) are membrane vesicles released from activated and apoptotic cells.

3. Leukocyte- and tumor-derived MPs express P-selectin glycoprotein-1 (PSGL-1) and bind to P-selectin that is expressed by activated endothelial cells and platelets.

4. Levels of TF-positive MPs are increased in various diseases, including sepsis and cancer.

5. TF-positive MPs may trigger venous thrombosis.

6. Inhibition of TF, the generation of MPs, and the binding of MPs to activated endothelial cells may be novel approaches to reduce venous thrombosis.

\section{Acknowledgments}

We would like to acknowledge Dr. R. Pawlinski and Dr. A.P. Owens for critical reading of the manuscript and funding from the National Institutes of Health and the University of North Carolina Cancer Research Fund.

\section{LITERATURE CITED}

1. Mackman N, Tilley RE, Key NS. Role of the extrinsic pathway of blood coagulation in hemostasis and thrombosis. Arterioscler. Thromb. Vasc. Biol. 2007; 27(8):1687-1693. [PubMed: 17556654]

2. Komiyama Y, Pedersen AH, Kisiel W. Proteolytic activation of human factors IX and X by recombinant human factor VIIa: effects of calcium, phospholipids, and tissue factor. Biochemistry. 1990; 29(40):9418-9425. [PubMed: 2248955]

3. Egorina EM, Sovershaev MA, Bjorkoy G, Gruber FX, Olsen JO, et al. Intracellular and surface distribution of monocyte tissue factor: application to intersubject variability. Arterioscler. Thromb. Vasc. Biol. 2005; 25(7):1493-1498. [PubMed: 15860742]

4. Drake TA, Morrissey JH, Edgington TS. Selective cellular expression of tissue factor in human tissues. Implications for disorders of hemostasis and thrombosis. Am. J. Pathol. 1989; 134(5):10871097. [PubMed: 2719077]

5. Fleck RA, Rao LV, Rapaport SI, Varki N. Localization of human tissue factor antigen by immunostaining with monospecific, polyclonal antihuman tissue factor antibody. Thromb. Res. 1990; 59(2):421-437. [PubMed: 2237820] 
6. Bouchard BA, Shatos MA, Tracy PB. Human brain pericytes differentially regulate expression of procoagulant enzyme complexes comprising the extrinsic pathway of blood coagulation.

Arterioscler. Thromb. Vasc. Biol. 1997; 17(1):1-9. [PubMed: 9012630]

7. Pawlinski R, Pedersen B, Schabbauer G, Tencati M, Holscher T, et al. Role of tissue factor and protease-activated receptors in a mouse model of endotoxemia. Blood. 2004; 103(4):1342-1347. [PubMed: 14576054]

8. Schwertz H, Tolley ND, Foulks JM, Denis MM, Risenmay BW, et al. Signal-dependent splicing of tissue factor premRNA modulates the thrombogenicity of human platelets. J. Exp. Med. 2006; 203(11):2433-2440. [PubMed: 17060476]

9. Butenas S, Bouchard BA, Brummel-Ziedins KE, Parhami-Seren B, Mann KG. Tissue factor activity in whole blood. Blood. 2005; 105(7):2764-2770. [PubMed: 15604222]

10. Key NS. Platelet tissue factor: How did it get there and is it important? Semin. Hematol. 2008; 45 Suppl. 1(2):16-20.

11. Osterud B, Bjorklid E. Sources of tissue factor. Semin. Thromb. Hemost. 2006; 32(1):11-23. [PubMed: 16479458]

12. Del Conde I, Shrimpton CN, Thiagarajan P, Lopez JA. Tissue-factor-bearing microvesicles arise from lipid rafts and fuse with activated platelets to initiate coagulation. Blood. 2005; 106(5):16041611. [PubMed: 15741221]

13. Zillmann A, Luther T, Muller I, Kotzsch M, Spannagl M, et al. Platelet-associated tissue factor contributes to the collagen-triggered activation of blood coagulation. Biochem. Biophys. Res. Commun. 2001; 281(2):603-609. [PubMed: 11181090]

14. Panes O, Matus V, Saez CG, Quiroga T, Pereira J, Mezzano D. Human platelets synthesize and express functional tissue factor. Blood. 2007; 109(12):5242-5250. [PubMed: 17347408]

15. Colucci M, Balconi G, Lorenzet R, Pietra A, Locati D, Donati MB, et al. Cultured human endothelial cells generate tissue factor in response to endotoxin. J. Clin. Investig. 1983; 71(6): 1893-1896. [PubMed: 6345590]

16. Bevilacqua MP, Pober JS, Majeau GR, Fiers W, Cotran RS, Gimbrone MA Jr. Recombinant tumor necrosis factor induces procoagulant activity in cultured human vascular endothelium: characterization and comparison with the actions of interleukin 1. Proc. Natl. Acad. Sci. USA. 1986; 83(12):4533-4537. [PubMed: 3487091]

17. Parry GC, Mackman N. Transcriptional regulation of tissue factor expression in human endothelial cells. Arterioscler. Thromb. Vasc. Biol. 1995; 15(5):612-621. [PubMed: 7749875]

18. Drake TA, Cheng J, Chang A, Taylor FB Jr. Expression of tissue factor, thrombomodulin, and Eselectin in baboons with lethal Escherichia coli sepsis. Am. J. Pathol. 1993; 142(5):1458-1470. [PubMed: 7684196]

19. Song D, Ye X, Xu H, Liu SF. Activation of endothelial intrinsic NF- $\kappa B$ pathway impairs protein C anticoagulation mechanism and promotes coagulation in endotoxemic mice. Blood. 2009; 114(12): 2521-2529. [PubMed: 19620400]

20. Semeraro N, Triggiani R, Montemurro P, Cavallo LG, Colucci M. Enhanced endothelial tissue factor but normal thrombomodulin in endotoxin-treated rabbits. Thromb. Res. 1993; 71(6):479486. [PubMed: 8134907]

21. Lupu C, Westmuckett AD, Peer G, Ivanciu L, Zhu H, et al. Tissue factor-dependent coagulation is preferentially up-regulated within arterial branching areas in a baboon model of Escherichia coli sepsis. Am. J. Pathol. 2005; 167(4):1161-1172. [PubMed: 16192650]

22. Pawlinski R, Pedersen B, Kehrle B, Aird WC, Frank RD, et al. Regulation of tissue factor and inflammatory mediators by Egr-1 in a mouse endotoxemia model. Blood. 2003; 101(10):39403947. [PubMed: 12543866]

23. Erlich J, Fearns C, Mathison J, Ulevitch RJ, Mackman N. Lipopolysaccharide induction of tissue factor expression in rabbits. Infect. Immun. 1999; 67(5):2540-2546. [PubMed: 10225918]

24. Hara S, Asada Y, Hatakeyama K, Marutsuka K, Sato Y, et al. Expression of tissue factor and tissue factor pathway inhibitor in rats lungs with lipopolysaccharide-induced disseminated intravascular coagulation. Lab. Investig. 1997; 77(6):581-589. [PubMed: 9426395] 
25. Mackman N, Sawdey MS, Keeton MR, Loskutoff DJ. Murine tissue factor gene expression in vivo. Tissue and cell specificity and regulation by lipopolysaccharide. Am. J. Pathol. 1993; 143(1): 76-84. [PubMed: 8317556]

26. Silverstein MD, Heit JA, Mohr DN, Petterson TM, O'Fallon WM, Melton LJ 3rd. Trends in the incidence of deep vein thrombosis and pulmonary embolism: a 25-year population-based study. Arch. Intern. Med. 1998; 158(6):585-593. [PubMed: 9521222]

27. Anderson FA Jr, Wheeler HB, Goldberg RJ, Hosmer DW, Patwardhan NA, et al. A populationbased perspective of the hospital incidence and case-fatality rates of deep vein thrombosis and pulmonary embolism. The Worcester DVT Study. Arch. Intern. Med. 1991; 151(5):933-938. [PubMed: 2025141]

28. Lilienfeld DE. Decreasing mortality from pulmonary embolism in the United States, 1979-1996. Int. J. Epidemiol. 2000; 29(3):465-469. [PubMed: 10869318]

29. Sevitt S. The structure and growth of valve-pocket thrombi in femoral veins. J. Clin. Pathol. 1974; 27(7):517-528. [PubMed: 4138834]

30. Wakefield TW, Myers DD, Henke PK. Mechanisms of venous thrombosis and resolution. Arterioscler. Thromb. Vasc. Biol. 2008; 28(3):387-391. [PubMed: 18296594]

31. Becker BF, Heindl B, Kupatt C, Zahler S. Endothelial function and hemostasis. Z. Kardiol. 2000; 89(3):160-167. [PubMed: 10798271]

32. Brooks EG, Trotman W, Wadsworth MP, Taatjes DJ, Evans MF, et al. Valves of the deep venous system: an overlooked risk factor. Blood. 2009; 114(6):1276-1279. [PubMed: 19436051]

33. Moll S, Mackman N. Venous thromboembolism: a need for more public awareness and research into mechanisms. Arterioscler. Thromb. Vasc. Biol. 2008; 28(3):367-369. [PubMed: 18296590]

34. Gibbs NM. Venous thrombosis of the lower limbs with particular reference to bed-rest. Br. J. Surg. 1957; 45(191):209-236. [PubMed: 13510687]

35. Warlow C, Ogston D, Douglas AS. Deep venous thrombosis of the legs after strokes. Part I: incidence and predisposing factors. Br. Med. J. 1976; 1(6019):1178-1181. [PubMed: 1268614]

36. Turpie AG, Gallus A, Beattie WS, Hirsh J. Prevention of venous thrombosis in patients with intracranial disease by intermittent pneumatic compression of the calf. Neurology. 1977; 27(5): 435-438. [PubMed: 558547]

37. Lopez JA, Chen J. Pathophysiology of venous thrombosis. Thromb. Res. 2009; 123 Suppl. 4:3034.

38. Hamer JD, Malone PC, Silver IA. The $\mathrm{PO}_{2}$ in venous valve pockets: its possible bearing on thrombogenesis. Br. J. Surg. 1981; 68(3):166-170. [PubMed: 7470818]

39. Lawson CA, Yan SD, Yan SF, Liao H, Zhou YS, et al. Monocytes and tissue factor promote thrombosis in a murine model of oxygen deprivation. J. Clin. Investig. 1997; 99(7):1729-1738. [PubMed: 9120018]

40. Burnier L, Fontana P, Kwak BR, Angelillo-Scherrer A. Cell-derived microparticles in haemostasis and vascular medicine. Thromb. Haemost. 2009; 101(3):439-451. [PubMed: 19277403]

41. Closse C, Seigneur M, Renard M, Pruvost A, Dumain P, et al. Influence of hypoxia and hypoxiareoxygenation on endothelial P-selectin expression. Thromb. Res. 1997; 85(2):159-164. [PubMed: 9058490]

42. Falati S, Liu Q, Gross P, Merrill-Skoloff G, Chou J, et al. Accumulation of tissue factor into developing thrombi in vivo is dependent upon microparticle P-selectin glycoprotein ligand 1 and platelet P-selectin. J. Exp. Med. 2003; 197(11):1585-1598. [PubMed: 12782720]

43. Thomas GM, Panicot-Dubois L, Lacroix R, Dignat-George F, Lombardo D, Dubois C. Cancer cellderived microparticles bearing P-selectin glycoprotein ligand 1 accelerate thrombus formation in vivo. J. Exp. Med. 2009; 206(9):1913-1927. [PubMed: 19667060]

44. Giesen PL, Rauch U, Bohrmann B, Kling D, Roque M, et al. Blood-borne tissue factor: another view of thrombosis. Proc. Natl. Acad. Sci. USA. 1999; 96(5):2311-2315. [PubMed: 10051638]

45. Morel O, Toti F, Hugel B, Bakouboula B, Camoin-Jau L, et al. Procoagulant microparticles: disrupting the vascular homeostasis equation? Arterioscler. Thromb. Vasc. Biol. 2006; 26(12): 2594-2604. [PubMed: 16990554] 
46. Misumi K, Ogawa H, Yasue H, Soejima H, Suefuji H, et al. Comparison of plasma tissue factor levels in unstable and stable angina pectoris. Am. J. Cardiol. 1998; 81(1):22-26. [PubMed: 9462600]

47. Tesselaar ME, Romijn FP, Van Der Linden IK, Prins FA, Bertina RM, Osanto S. Microparticleassociated tissue factor activity: a link between cancer and thrombosis? J. Thromb. Haemost. 2007; 5(3):520-527. [PubMed: 17166244]

48. Shet AS, Aras O, Gupta K, Hass MJ, Rausch DJ, et al. Sickle blood contains tissue factor-positive microparticles derived from endothelial cells and monocytes. Blood. 2003; 102(7):2678-2683. [PubMed: 12805058]

49. Aras O, Shet A, Bach RR, Hysjulien JL, Slungaard A, et al. Induction of microparticle- and cellassociated intravascular tissue factor in human endotoxemia. Blood. 2004; 103(12):4545-4553. [PubMed: 14988149]

50. Chou J, Mackman N, Merrill-Skoloff G, Pedersen B, Furie BC, Furie B. Hematopoietic cellderived microparticle tissue factor contributes to fibrin formation during thrombus propagation. Blood. 2004; 104(10):3190-3197. [PubMed: 15280200]

51. Hoffman M, Whinna HC, Monroe DM. Circulating tissue factor accumulates in thrombi, but not in hemostatic plugs. J. Thromb. Haemost. 2006; 4(9):2092-2093. [PubMed: 16961625]

52. Furie B, Furie BC. Mechanisms of thrombus formation. N. Engl. J. Med. 2008; 359(9):938-949. [PubMed: 18753650]

53. Himber J, Wohlgensinger C, Roux S, Damico LA, Fallon JT, et al. Inhibition of tissue factor limits the growth of venous thrombus in the rabbit. J. Thromb. Haemost. 2003; 1(5):889-895. [PubMed: 12871353]

54. Biro E, Sturk-Maquelin KN, Vogel GM, Meuleman DG, Smit MJ, et al. Human cell-derived microparticles promote thrombus formation in vivo in a tissue factor-dependent manner. J. Thromb. Haemost. 2003; 1(12):2561-2568. [PubMed: 14738565]

55. Szalony JA, Suleymanov OD, Salyers AK, Panzer-Knodle SG, Blom JD, et al. Administration of a small molecule tissue factor/factor VIIa inhibitor in a nonhuman primate thrombosis model of venous thrombosis: effects on thrombus formation and bleeding time. Thromb. Res. 2003; 112(3): 167-174. [PubMed: 14967414]

56. Zhou J, May L, Liao P, Gross PL, Weitz JI. Inferior vena cava ligation rapidly induces tissue factor expression and venous thrombosis in rats. Arterioscler. Thromb. Vasc. Biol. 2009; 29(6):863-869. [PubMed: 19265029]

57. Day SM, Reeve JL, Pedersen B, Farris DM, Myers DD, et al. Macrovascular thrombosis is driven by tissue factor derived primarily from the blood vessel wall. Blood. 2005; 105(1):192-198. [PubMed: 15339841]

58. Koellnberger M, Von Bruehl M, Bergmeier W, Wagner D, Mackman N, Massberg S. Platelets contribute to arterial and venous thrombosis in vivo. Circulation. 2007; 116(16 Suppl.) II_75, Abstr. 448.

59. Khorana AA, Francis CW, Culakova E, Kuderer NM, Lyman GH. Thromboembolism is a leading cause of death in cancer patients receiving outpatient chemotherapy. J. Thromb. Haemost. 2007; 5(3):632-634. [PubMed: 17319909]

60. Heit JA. Cancer and venous thromboembolism: scope of the problem. Cancer Control. 2005; 12 Suppl. 1:5-10. [PubMed: 16179898]

61. Dvorak HF, Van DeWater L, Bitzer AM, Dvorak AM, Anderson D, et al. Procoagulant activity associated with plasma membrane vesicles shed by cultured tumor cells. Cancer Res. 1983; 43(9): 4434-4442. [PubMed: 6347372]

62. Yu JL, May L, Lhotak V, Shahrzad S, Shirasawa S, et al. Oncogenic events regulate tissue factor expression in colorectal cancer cells: implications for tumor progression and angiogenesis. Blood. 2005; 105(4):1734-1741. [PubMed: 15494427]

63. Davila M, Amirkhosravi A, Coll E, Desai H, Robles L, et al. Tissue factor-bearing microparticles derived from tumor cells: impact on coagulation activation. J. Thromb. Haemost. 2008; 6(9):15171524. [PubMed: 18433463]

64. White RH, Chew H, Wun T. Targeting patients for anticoagulant prophylaxis trials in patients with cancer: Who is at highest risk? Thromb. Res. 2007; 120 Suppl. 2:29-40. [PubMed: 16887171] 
65. Kakkar AK, Lemoine NR, Scully MF, Tebbutt S, Williamson RC. Tissue factor expression correlates with histological grade in human pancreatic cancer. Br. J. Surg. 1995; 82(8):1101-1104. [PubMed: 7648165]

66. Khorana AA, Ahrendt SA, Ryan CK, Francis CW, Hruban RH, et al. Tissue factor expression, angiogenesis, and thrombosis in pancreatic cancer. Clin. Cancer Res. 2007; 13(10):2870-2875. [PubMed: 17504985]

67. Khorana AA, Francis CW, Menzies KE, Wang JG, Hyrien O, et al. Plasma tissue factor may be predictive of venous thromboembolism in pancreatic cancer. J. Thromb. Haemost. 2008; 6(11): 1983-1985. [PubMed: 18795992]

68. Tesselaar ME, Romijn FP, Van Der Linden IK, Bertina RM, Osanto S. Microparticle-associated tissue factor activity in cancer patients with and without thrombosis. J. Thromb. Haemost. 2009; 7(8):1421-1423. [PubMed: 19500241]

69. Manly DA, Wang J, Glover SL, Kasthuri R, Liebman HA, et al. Increased microparticle tissue factor activity in cancer patients with Venous Thromboembolism. Thromb. Res. 2010; 125(6): 511-512. [PubMed: 19854471]

70. Hron G, Kollars M, Weber H, Sagaster V, Quehenberger P, et al. Tissue factor-positive microparticles: cellular origin and association with coagulation activation in patients with colorectal cancer. Thromb Haemost. 2007; 97(1):119-123. [PubMed: 17200778]

71. Zwicker JI, Liebman HA, Neuberg D, Lacroix R, Bauer KA, et al. Tumor-derived tissue factorbearing microparticles are associated with venous thromboembolic events in malignancy. Clin. Cancer Res. 2009; 15(22):6830-6840. [PubMed: 19861441]

72. Kasthuri RS, Taubman MB, Mackman N. Role of tissue factor in cancer. J. Clin. Oncol. 2009; 27(29):4834-4838. [PubMed: 19738116]

73. Ay C, Simanek R, Vormittag R, Dunkler D, Alguel G, et al. High plasma levels of soluble Pselectin are predictive of venous thromboembolism in cancer patients: results from the Vienna Cancer and Thrombosis Study (CATS). Blood. 2008; 112(7):2703-2708. [PubMed: 18539899]

74. Uno K, Homma S, Satoh T, Nakanishi K, Abe D, et al. Tissue factor expression as a possible determinant of thromboembolism in ovarian cancer. Br. J. Cancer. 2007; 96(2):290-295. [PubMed: 17211468]

75. Ay C, Vormittag R, Dunkler D, Simanek R, Chiriac AL, et al. D-dimer and prothrombin fragment $1+2$ predict venous thromboembolism in patients with cancer: results from the Vienna Cancer and Thrombosis Study. J. Clin. Oncol. 2009; 27(25):4124-4129. [PubMed: 19636003]

76. Clagett GP, Reisch JS. Prevention of venous thromboembolism in general surgical patients. Results of meta-analysis. Ann. Surg. 1988; 208(2):227-240. [PubMed: 2456748]

77. Rosendaal FR. Venous thrombosis: the role of genes, environment, and behavior. Hematol. Am. Soc. Hematol. Educ. Program. 2005:1-12.

78. Johnson GJ, Leis LA, Bach RR. Tissue factor activity of blood mononuclear cells is increased after total knee arthroplasty. Thromb. Haemost. 2009; 102(4):728-734. [PubMed: 19806259]

79. Geerts WH, Code KI, Jay RM, Chen E, Szalai JP. A prospective study of venous thromboembolism after major trauma. N. Engl. J. Med. 1994; 331(24):1601-1606. [PubMed: 7969340]

80. Mammen EF. Pathogenesis of venous thrombosis. Chest. 1992; 102(6 Suppl.):640-644. [PubMed: 1643967]

81. Nieuwland R, Berckmans RJ, Rotteveel-Eijkman RC, Maquelin KN, Roozendaal KJ, et al. Cellderived microparticles generated in patients during cardiopulmonary bypass are highly procoagulant. Circulation. 1997; 96(10):3534-3541. [PubMed: 9396452]

82. Mackman N. Triggers, targets and treatments for thrombosis. Nature. 2008; 451(7181):914-918. [PubMed: 18288180]

83. Mackman N, Becker RC. DVT: a new era in anticoagulant therapy. Arterioscler. Thromb. Vasc. Biol. 2010; 30(3):369-371. [PubMed: 20139354]

84. Key NS, Kasthuri RS. Current treatment of venous thromboembolism. Arterioscler. Thromb. Vasc. Biol. 2010; 30(3):372-375. [PubMed: 20139364]

85. Perzborn E. Factor Xa inhibitors: new anticoagulants for secondary haemostasis. Hamostaseologie. 2009; 29(3):260-267. [PubMed: 19644596] 
86. Perzborn E, Roehrig S, Straub A, Kubitza D, Mueck W, Laux V. Rivaroxaban: a new oral factor Xa inhibitor. Arterioscler. Thromb. Vasc. Biol. 2010; 30(3):376-381. [PubMed: 20139357]

87. Curtis AM, Wilkinson PF, Gui M, Gales TL, Hu E, Edelberg JM. p38 mitogen-activated protein kinase targets the production of proinflammatory endothelial microparticles. J. Thromb. Haemost. 2009; 7(4):701-709. [PubMed: 19192109]

88. Wakefield TW, Myers DD, Henke PK. Role of selectins and fibrinolysis in VTE. Thromb. Res. 2009; 123 Suppl. 4:35-40. 


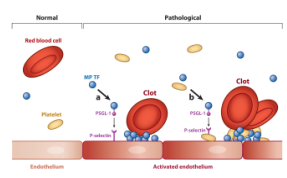

Figure 1.

Formation of a venous clot. Venous thrombi are fibrin-rich clots that develop in the absence of gross endothelial damage. In a healthy vein (left), high levels of tissue factor pathway inhibitor (TFPI), thrombomodulin (TM), and endothelial cell protein $\mathrm{C}$ receptor (EPCR) maintain an antithrombotic phenotype (normal endothelium). In pathological conditions (right), elevated levels of tissue factor (TF)-positive microparticles (MPs) are present in the blood, and reduced blood flow, activation of the venous endothelium, and deposition of platelets may conspire to trigger formation of a thrombotic clot. Here we present two potential mechanisms that initiate activation of the coagulation system: (a) TF-positive MPs expressing P-selectin glycoprotein-1 (PSGL-1) dock to an activated endothelium expressing P-selectin, and (b) TF-positive MPs bind to activated platelets that adhere to the activated endothelium. In both cases, the presence of MP TF serves as a potent trigger of coagulation activation, and the continuous delivery of TF-positive MPs may enhance propagation of the thrombus. 